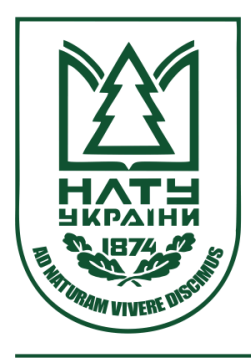

Науковий вісник НлтУ України Scientific Bulletin of UNFU

http://nv.nltu.edu.ua

https://doi.org/10.15421/40281110

$@ \bowtie$ Correspondence author

Article received $12.12 .2018 \mathrm{p}$.

Article accepted 27.12.2018 p.

V. Yu. Yukhnovskyi yukhnov@ukr.net

УДК $630 *[64+116+43]$

В. Ю. Юхновський 1 , І. А. Проценко ${ }^{1}$, В. М. Хрик ${ }^{2}$

${ }^{l}$ Національний університет біоресурсів і природокористування України, м. Київ, Украӥна

${ }^{2}$ Білочерківський начіональний аграрний університет, м. Біла Церква, Україна

\title{
САНІТАРНИЙ СТАН СОСНОВИХ НАСАДЖЕНЬ НА РЕКУЛЬТИВОВАНИХ ЗЕМЛЯХ
}

Проаналізовано санітарний стан соснових насаджень, створених на рекультивованих землях Юрківського буровугільного кар'єру. Насадження ростуть у складних умовах на переміщених, малопотужних грунтах із вуглистими пісками. За даними 61 кругової пробної площі, які охоплюють типові умови зростання соснових культур на площі 141,1 га, обчислено показники санітарного стану насаджень. Аналіз показника санітарного стану показав, що соснові насадження належать до сильно ослаблених. Ослаблені дерева сосни становлять 44,7 \%, а показник санітарного стану змінюється у межах 3,01-3,41. Стан соснових насаджень V класу віку наближається до категорії насаджень, що всихають 3 найвищою величиною показника стану 3,41 . Встановлено, що найвпливовішими чинниками істотного погіршення санітарного стану соснових культур на рекультивованих землях Юрківського буровугільного басейну є ураження кореневою губкою і всихання дерев унаслідок зменшення живлення рослин, які досягли порушеного материнського горизонту на глибині понад 40-50 см. Для запобігання розвитку кореневої губки необхідно створювати мішані культури сосни звичайної з введенням до 50 \% листяних порід, які водночас будуть протипожежним бар'єром поширення низових пожеж. Для оздоровлення соснових насаджень, підвищення меліоративної ефективності та ліквідації осередків кореневої губки доцільно проводити суцільні санітарні рубки 3 подальшим висаджуванням листяних порід.

Ключові слова: категорії стану; показник санітарного стану; склад; повнота; сухостій.

Вступ. Штучні насадження на рекультивованих землях Юрківського буровугільного кар'єру, яких було створено після його виробки у 70-80-х роках минулого століття, перебувають сьогодні у фазі формування найпродуктивніших деревостанів. Резонно, що стійкість лісових культур, порівняно зі стійкістю природних насаджень, істотно знижена відносно більшості негативних чинників зовнішнього середовища. Життєздатність штучних деревостанів та їх належний стан підтримуються завдяки проведенню науково обгрунтованих лісогосподарських заходів, які регулюють процеси природного самозрідження, усувають наслідки негативного впливу природних і антропогенних чинників (Khryk, 2010).

Від стану лісів багато в дечому залежить ріст і захисні властивості насаджень. Останнім часом погіршився санітарний стан лісів у різних регіонах України, що пов'язано зі змінами клімату та антропогенним впливом (Kopii \& Kucheriavyi, 2015; Lavrov \& Miroshnyk, 2009). Тенденція зниження стійкості насаджень особливо чітко проявляється у чистих сосняках, зростаючих на деградованих грунтах девастованих ландшафтів.

Мета дослідження - визначити санітарний стан соснових насаджень на рекультивованих землях, виявити вплив біотичних і абіотичних чинників на зміни стану насаджень і надати рекомендації з підвищення біологічної стійкості сосняків в умовах природного й антропогенного навантаження.

Матеріал і методи дослідження. Об'єктом дослідження були соснові насадження на рекультивованих землях Юрківського буровугільного кар'єру. Соснові насадження у лісомеліоративному фонді є переважаючими і займають 47,6 \% від загальної площі та досягли $\mathrm{V}$ класу віку. Дослідженнями охоплено соснові насадження на площі 141,1 га (табл. 1), що становить понад $40 \%$ всіх соснових насаджень об'єкта досліджень (Yukhnovskyi, Lobchenko \& Protsenko, 2018).

Табл. 1. Лісівничо-таксаційна характеристика соснових насаджень

\begin{tabular}{|c|c|c|c|c|c|c|c|c|}
\hline $\begin{array}{l}\text { No } \\
3 / \Pi\end{array}$ & $\begin{array}{c}\text { Квар- } \\
\text { тал, } \\
\text { виділ }\end{array}$ & $\begin{array}{c}\text { Пло- } \\
\text { ща, } \\
\text { га }\end{array}$ & & $\begin{array}{c}\text { Дi- } \\
\text { амет } \\
\text { p, cм }\end{array}$ & $\begin{array}{c}\text { Ви- } \\
\text { сота, } \\
\text { м }\end{array}$ & $\begin{array}{c}\text { Боні- } \\
\text { тет }\end{array}$ & & 3a- \\
\hline & & 21,0 & & 18,4 & & & & \\
\hline & & & & J & & & & \\
\hline & & & & 0,1 & , & & & 83 \\
\hline & & & & 19,5 & 17 & & & 19 \\
\hline 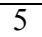 & $T$ & 2,5 & & 22,6 & 20,4 & I & 81 & 212 \\
\hline & $91 / 9$ & 8,6 & $8 \mathrm{C} 32$ БП & 24,8 & 20,1 & $\mathrm{I}$ & 0,79 & 253 \\
\hline
\end{tabular}

Більшість соснових насаджень представлено чистими за складом деревостанами 3 незначною домішкою

Інформація про авторів:

Юхновський Василь Юрійович, д-р с.-г. наук, професор, кафедра відтворення лісів та лісових меліорацій. Email: yukhnov@nubip.edu.ua

Проценко Ігор Анатолійович, аспірант, кафедра відтворення лісів та лісових меліорацій. Email: protiga4@gmail.com

Хрик Василь Михайлович, канд. с.-г. наук, доцент, кафедра лісівництва, ботаніки і фізіології рослин. Email: khryk@ukr.net, svtmzel@gmail.com

Цитування за ДСту: Юхновський В. Ю., Проценко І. А., Хрик В. М. Санітарний стан соснових насаджень на рекультивованих землях. Науковий вісник НлтУ України. 2018, т. 28, № 11. С. 55-59.

Citation APA: Yukhnovskyi, V. Yu., Protsenko, I. A., \& Khryk, V. M. (2018). Sanitary state of pine plantations on reclaimed land. Scientific Bulletin of UNFU, 28(11), 55-59. https://doi.org/10.15421/40281110 
берези повислої, дуба звичайного й робінії звичайної (квартали 82, 83, 86, 89). Мішані насадження 3 домішкою 2-х одиниць берези повислої займають лише площу 21,1 га (кв. 90, 91). Усі сосняки зростають в умовах свіжого сугруду $\left(\mathrm{C}_{2}\right)$.

Насадження I і II класів бонітету зазвичай середньоповнотні. Лише у кварталі 89 повнота становить 0,46, що пов'язано 3 рубками догляду, проведеними у 2017 р. Запас насаджень змінюється в межах 155$253 \mathrm{~m}^{3} /$ га. У підрості спостерігаємо самосів робінії звичайної, дуба червоного, клена ясенелистого. Різноманіття підліску представлено горобиною звичайною, дереном криваво-червоний, жимолостю татарською. Жи-

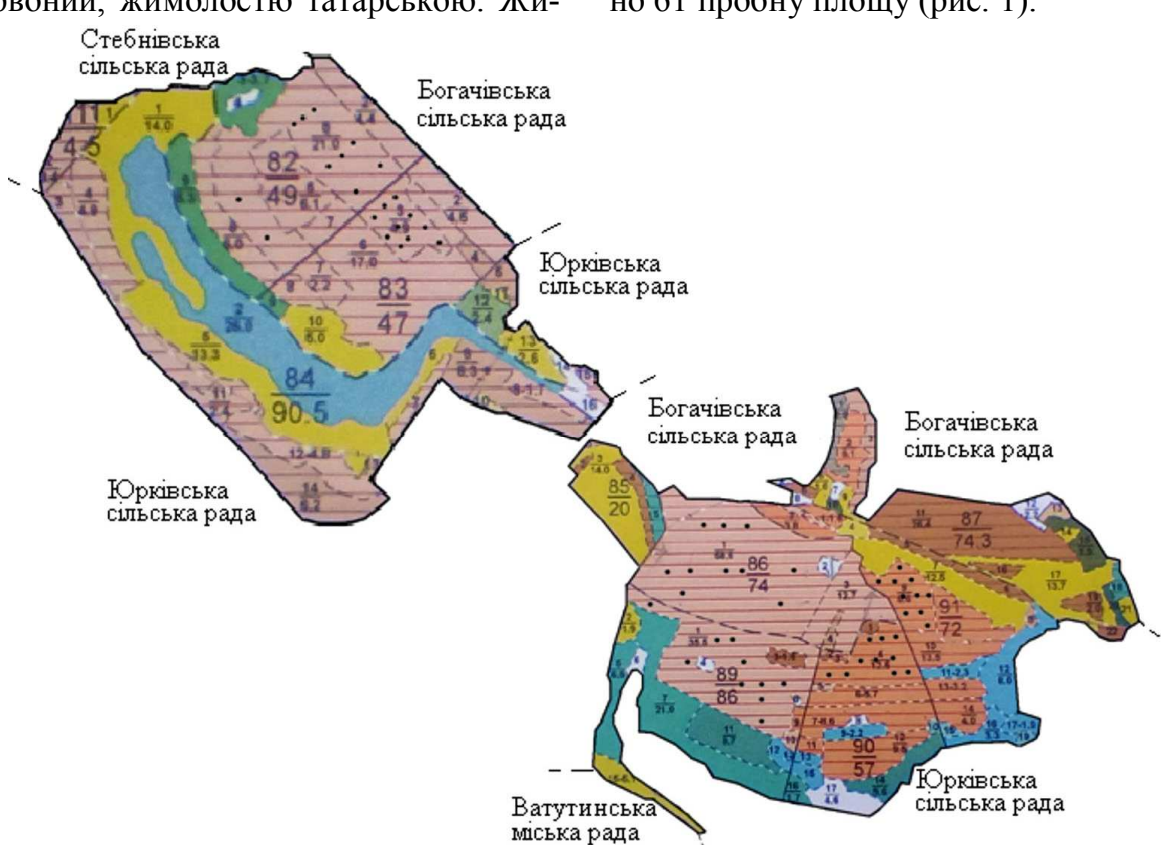

міська рада вий надгрунтовий покрив розміщений нерівномірно (плямами) з проективним покриттям 5-20\% 3 такими рослинами: осока, вівсюг, фіалка, полинь, суниця.

На прогалинах і мікропониженнях у сприятливих умовах відзначено куртини самосіву сосни, що свідчить про можливість природного поновлення соснових насаджень.

Визначення санітарного стану насаджень проводили на кругових пробних площах, розміщених у типових місцях 3 охопленням всієї території цих великих масивів. Це соснові насадження у кварталах 82, 83, 86, 89, 90 і 91 з площами від 28 до 64 га. Всього було закладено 61 пробну площу (рис. 1).

Рис. 1. План лісових насаджень на рекультивованих землях Юрківського буровугільного кар'єру (- місця закладання кругових пробних площ)

На пробних площах, із використанням призми М. П. Анучина (Anuchin, 1982), здійснювали перелік дерев за категоріями стану. Для дослідження санітарного стану насаджень використано методику, затверджену санітарними правилами в лісах України (Sanitarni pravyla v lisakh Ukrainy, 1995).

Під час переліку дерев на пробних площах для кожного 3 них визначали категорію стану за сумою біоморфологічних ознак, до яких відносили густоту і колір крони, наявність і характер розподілу хвої, ураженість останньої некрозами інфекційного та неінфекційного характеру, шкідниками й патогенами, відносний приріст пагонів і деревини, вік хвої, яка зберігається на пагонах, наявність сухих гілок, стан кори й лубу тощо (Mozolevskaia, 1998; Mozolevskaia, Kataev \& Sokolova, 1984). За шкалою (Lavrov \& Miroshnyk, 2009) виділяли шість категорій стану дерев - здорові, ослаблені, дуже ослаблені, всихаючі та сухостій (свіжий і минулих років). За їхнім співвідношенням розраховували загальний показник стану дерев (інакше - показник санітарного стану насаджень) I за формулою (Yukhnovskyi, Lobchenko \& Protsenko, 2018)

$$
I=\sum_{i=1}^{6} i \cdot n_{i} / \sum_{i=1}^{6} n_{i},
$$

де $n_{1}, n_{2}, \ldots, n_{6}$ - кількість дерев відповідної категорії санітарного стану.
Показник стану живих дерев визначали за такою формулою

$$
I=\sum_{i=1}^{4} i \cdot n_{i} / \sum_{i=1}^{4} n_{i} .
$$

Ступінь ослаблення або насадження на виділах визначали як середньозважену величину оцінок розподілу дерев різних категорій стану. Стан насадження встановлювали за такими величинами показника санітарного стану: до 1,5 - здорові насадження; 1,6-2,5 - ослаблені; 2,6-3,5 - сильно ослаблені; 3,6-4,5 - насадження, що всихають; понад 4,5 - загиблі. Під час польових робіт на пробних площах фіксували всі прояви негативного впливу на стан лісових фітоценозів інших біотичних i абіотичних чинників (шкідники й захворювання лісу, лісові пожежі, пошкодження пізніми заморозками, а також дикими і свійськими тваринами тощо).

Математичне та статистичне опрацювання результатів виконували за допомогою програмних пакетів Місrosoft Excel (Hrom, 2007).

Результати дослідження. Важливими аспектами лісової рекультивації та відновлення девастованих ландшафтів є повернення землі в господарське використання, запобігання негативним наслідкам природно-територіальних комплексів, створення на місці порушених земель більш продуктивних і раціонально організованих елементів культурних ландшафтів, покращення умов навколишнього середовища (Kopii \& Kucheriavyi, 2015). 
За описаною вище методикою на кожній круговій пробній площі в межах досліджуваних об'єктів визначали показник санітарного стану за формулою 1. Фрагмент визначення санітарного стану соснових насаджень наведено у табл. 2. Узагальнені дані за всіма об'єктами занесено у табл. 3, а відсотковий розподіл загальної кількості дерев за категоріями санітарного стану дерев ілюстровано на рис. 2 .

Дані табл. 3 свідчать, що всі соснові насадження належать до сильно ослаблених, де показник санітарного стану змінюється в межах 3,01-3,41. Стан соснових насаджень V класу віку наближається до насаджень, що всихають, $з$ показником санітарного стану 3,41. Сильно ослаблений стан сосняків підтверджуємо 3 рис. 2, на якому видно, що 44,7 \% дерев у насадженнях - це ослаблені екземпляри.

Табл. 2. Санітарний стан насадження (квартал 86, виділ 1)

\begin{tabular}{|c|c|c|c|c|c|c|c|c|}
\hline \multirow{3}{*}{$\begin{array}{c}\text { Номер } \\
\text { пробної площі }\end{array}$} & \multicolumn{6}{|c|}{ Категорія стану дерев } & \multirow{3}{*}{$\begin{array}{l}\text { Кількість дерев на } \\
\text { пробній площі, шт. }\end{array}$} & \multirow{3}{*}{$\begin{array}{c}\text { Показник санітар- } \\
\text { ного стану }\end{array}$} \\
\hline & $\mathrm{I}$ & II & III & IV & $\mathrm{V}$ & $\mathrm{VI}$ & & \\
\hline & \multicolumn{6}{|c|}{ кількість дерев за категоріями стану, шт. } & & \\
\hline 1 & 4 & 12 & 17 & 3 & 1 & 0 & 37 & 2,59 \\
\hline 2 & 1 & 5 & 13 & 3 & 4 & 4 & 30 & 3,53 \\
\hline 3 & 0 & 8 & 14 & 4 & 1 & 0 & 27 & 2,93 \\
\hline 4 & 2 & 14 & 3 & 8 & 3 & 0 & 30 & 2,87 \\
\hline 5 & 1 & 9 & 12 & 7 & 2 & 1 & 32 & 3,09 \\
\hline 6 & 3 & 10 & 11 & 6 & 2 & 2 & 34 & 3,00 \\
\hline 7 & 2 & 8 & 13 & 7 & 1 & 1 & 32 & 3,00 \\
\hline 8 & 1 & 8 & 10 & 8 & 2 & 0 & 29 & 3,07 \\
\hline 9 & 2 & 9 & 13 & 7 & 1 & 1 & 33 & 2,97 \\
\hline 10 & 3 & 9 & 11 & 8 & 2 & 1 & 34 & 3,00 \\
\hline \multicolumn{8}{|c|}{ Середньозважений показник санітарного стану } & 3,01 \\
\hline
\end{tabular}

Табл. 3. Санітарний стан соснових насаджень на виділах

\begin{tabular}{|c|c|c|c|c|c|c|c|c|c|c|}
\hline \multirow[t]{2}{*}{ Кв./вид. } & \multirow[t]{2}{*}{ Склад } & \multirow[t]{2}{*}{ Вік, років } & \multicolumn{6}{|c|}{$\begin{array}{c}\text { Кількість дерев за категоріями стану: чисельник, шт., } \\
\text { знаменник, \% }\end{array}$} & \multirow{2}{*}{$\begin{array}{c}\text { Кількість дерев на } \\
\text { пробних площах, шт. }\end{array}$} & \multirow[t]{2}{*}{ Icc } \\
\hline & & & I & II & III & IV & $\mathrm{V}$ & VI & & \\
\hline \multirow{2}{*}{$82 / 5$} & \multirow{2}{*}{$10 \mathrm{C}_{3}+Б п+А \kappa$} & \multirow{2}{*}{38} & 8 & 53 & 124 & 23 & 18 & 5 & 231 & \multirow{2}{*}{3,29} \\
\hline & & & 3,5 & 22,9 & 53,7 & 10,0 & 7,8 & 2,2 & 100 & \\
\hline \multirow{2}{*}{$83 / 3$} & \multirow{2}{*}{$10 \mathrm{C} 3$} & \multirow{2}{*}{39} & 12 & 44 & 78 & 48 & 25 & 11 & 218 & \multirow{2}{*}{3,03} \\
\hline & & & 5,5 & 20,2 & 35,8 & 22,0 & 11,5 & 5,0 & 100 & \\
\hline \multirow{2}{*}{$86 / 1$} & \multirow{2}{*}{$10 \mathrm{C}_{3}+Д 3+Б п$} & \multirow{2}{*}{41} & 19 & 92 & 117 & 61 & 19 & 10 & 318 & \multirow{2}{*}{3,01} \\
\hline & & & 6,0 & 28,9 & 36,8 & 19,2 & 6,0 & 3,1 & 100 & \\
\hline \multirow{2}{*}{$89 / 1$} & \multirow{2}{*}{$10 \mathrm{C}_{3}+$ Бп } & \multirow{2}{*}{43} & 5 & 80 & 174 & 39 & 20 & 18 & 336 & \multirow{2}{*}{3,14} \\
\hline & & & 1,5 & 23,8 & 51,8 & 11,6 & 6,0 & 5,4 & 100 & \\
\hline \multirow{2}{*}{$90 / 4$} & \multirow{2}{*}{ 8Сз2Бп } & \multirow{2}{*}{43} & 3 & 70 & 119 & 38 & 27 & 17 & 274 & \multirow{2}{*}{3,25} \\
\hline & & & 1,1 & 25,5 & 43,4 & 13,9 & 9,9 & 6,2 & 100 & \\
\hline \multirow{2}{*}{$91 / 9$} & \multirow{2}{*}{ 8Сз2Бп } & \multirow{2}{*}{50} & 3 & 45 & 126 & 55 & 30 & 16 & 275 & \multirow{2}{*}{3,41} \\
\hline & & & 1,1 & 16,4 & 45,8 & 20,0 & 10,9 & 5,8 & 100 & \\
\hline
\end{tabular}

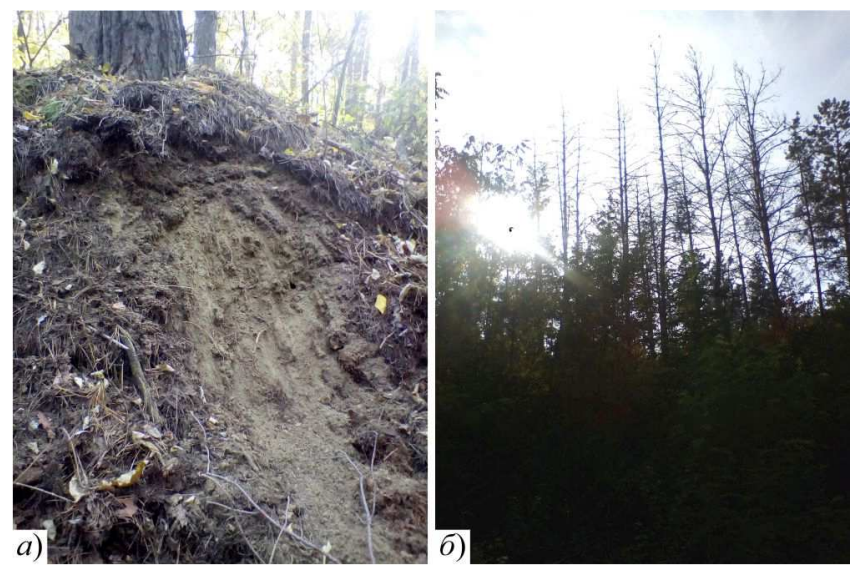

Рис. 3. а) - грунтовий профіль у насадженнях буровугільного кар'єру (кв. 90, вид. 4); б) - осередок кореневої губки у 50-річному насадженні сосни звичайної (кв. 91, вид. 9)

Головною причиною ослаблення соснових насаджень $є$ переміщені грунти, родючий шар яких становить лише 20-40 см (рис. 3, a). Рослинам не вистачає по-

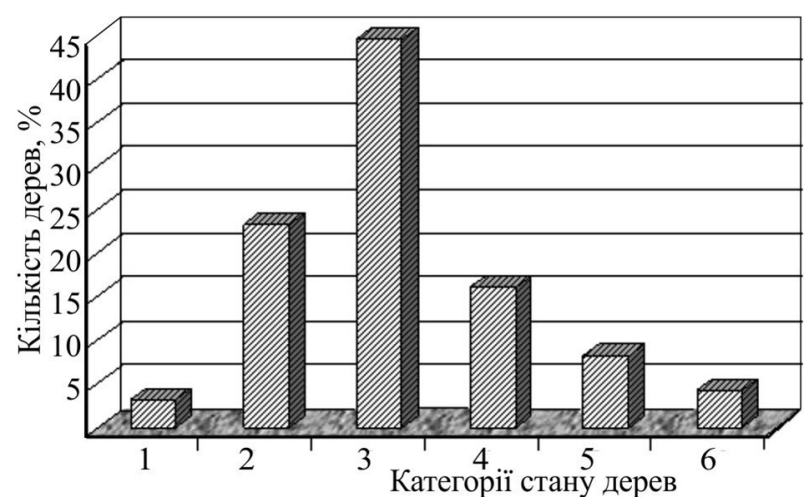

Рис. 2. Розподіл кількості дерев за категоріями санітарного стану 
покриву), який формується у середньовікових штучних соснових насадженнях свіжої субору, свідчить про відновлення флористичного різноманіття рекультивованих земель способом лісової меліорації.

3 аналізу показника санітарного стану видно, що соснові насадження належить до сильно ослаблених. Ослаблені дерева сосни складають 44,7 \%, а показник санітарного стану змінюється у межах 3,01-3,41. Стан соснових насаджень V класу віку наближається до категорії насаджень, що всихають, $з$ найвищою величиною показника стану 3,41 .

Встановлено, що найвпливовішими чинниками icтотного погіршення санітарного стану соснових культур на рекультивованих землях Юрківського буровугільного басейну є ураження кореневою губкою і всихання дерев внаслідок зменшення живлення рослин, які досягли порушеного материнського горизонту на глибині понад 40-50 cм.

На рекультивованих землях необхідно вирощувати сосну у змішаних із листяними породами насадженнях 3 використанням усіх можливостей природного поновлення цієї породи. Негативний вплив локальних i екстремальних ситуацій на стан і ріст соснових культур потрібно мінімізувати головним чином, системою профілактичних заходів, спрямованих на запобігання ураженню соснових деревостанів кореневою губкою і виникненню лісових пожеж. Вчасне проведення системи заходів уже в молодняках забезпечує зменшення природного відпаду, розмір надмірної вибірки дерев за санітарним станом i, відповідно, зниження повноти й кількості дерев на одиницю площі.

На рекультивованих землях Юрківського буровугільного басейну з метою запобігання розвитку кореневої губки необхідно створювати змішані культури сосни звичайної з введенням до 50 \% листяних порід, які водночас будуть протипожежним бар'єром поширення низових пожеж.

Для оздоровлення соснових насаджень, підвищення меліоративної ефективності та ліквідації осередків кореневої губки в зоні сильного ураження потрібно проводити суцільні санітарні рубки з подальшим висаджуванням листяних порід.

\section{Перелік використаних джерел}

Anuchin, N. P. (1982). Lesnaia taksatciia. Moscow: Lesn. prom-st, 552 p. [In Russian].

Hrom, M. M. (2007). Lisova taksatsiia. Lviv: RVV NLTU Ukrainy, 416 p. [In Ukrainian].

Khryk, V. M. (2010). Stan kultur sosny na erodovanykh zemliakh Prydniprovia. Visnyk naukovykh prats KhNAU, 5, 172-179. [In Ukrainian].

Kopii, M. L., \& Kucheriavyi, V. P. (2015). Analiz fiziolohichnykh zmin roslyn v umovakh porushenykh zemel Yavorivskoho sirchanoho karieru. Scientific Bulletin of UNFU, 25(10), 166-173. [In Ukrainian].

Lavrov, V. V., \& Miroshnyk, N. V. (2009). Antropohennyi vplyv na sosnovi nasadzhennia Cherkaskoho boru. Visnyk KNU, 22-24, 142-144. [In Ukrainian].

Mozolevskaia, E. G. (1998). Metody otcenki i prognoza dinamiki sostoianiia nasazhdenii. Lesnoe khoziaistvo, 8, 43-45. [In Russian].

Mozolevskaia, E. G., Kataev, O. A., \& Sokolova, E. S. (1984). Metody lesopatologicheskogo obsledovaniia ochagov stvolovikh vreditelei i boleznei lesa. Moscow: Lesnaia promyshlennost, 152 p. [In Russian].

Sanitarni pravyla v lisakh Ukrainy. (1995). Postanova Kabinetu Ministriv Ukrainy vid 27.07.1995 r., № 555. Kyiv: Urozhai, 16 p. [In Ukrainian].

Yukhnovskyi, V. Yu., Lobchenko, H. O., \& Protsenko, I. A. (2018). Osoblyvosti rostu sosnovykh nasadzhen na rekultyvovanykh zemliakh. Scientific Bulletin of UNFU, 28(7), 70-73. https://doi.org/10.15421/40280715

В. Ю. Юхновский1, И. А. Проценко1, В. М. Хрык 2

${ }^{I}$ Национальный университет биоресурсов и природопользования Украины, г. Киев, Украина

${ }^{2}$ Белочерковский национальный аграрный университет, г. Белая Церковь, Украина

\section{САНИТАРНОЕ СОСТОЯНИЕ СОСНОВЫХ НАСАЖДЕНИЙ НА РЕКУЛЬТИВИРОВАННЫХ ЗЕМЛЯХ}

Произведен анализ санитарного состояния сосновых насаждений, созданных на рекультивированных землях Юрковского буроугольного карьера. Насаждения растут в сложных условиях на перемещенных, маломощных почвах с углистыми песками. По данным 61 круговой пробной площади, которые охватывают типовые условия произрастания сосновых культур на территории 141,1 га, вычислены индексы санитарного состояния насаждений. Анализ индекса санитарного состояния показал, что сосновые насаждения относятся к сильно ослабленным. Ослабленные деревья сосны составляют 44,7 \%, а индекс санитарного состояния колеблется в пределах 3,01-3,41. Состояние сосновых насаждений V класса возраста приближается к категории усыхающих насаждений с высокой величиной индекса состояния 3,41 . Установлено, что самыми влиятельными факторами существенного ухудшения санитарного состояния сосновых культур на рекультивированных землях Юрковского буроугольного бассейна являются поражение корневой губкой и усыхание деревьев вследствие уменьшения площади питания растений, которые достигли нарушенного материнского горизонта на глубине более 40-50 см. С целью предотвращения развития корневой губки необходимо создавать смешанные культуры сосны обыкновенной с введением до $50 \%$ лиственных пород, которые одновременно будут служить противопожарным барьером распространения низовых пожаров. Для оздоровления сосновых насаждений, повышения мелиоративной эффективности и ликвидации очагов корневой губки целесообразно проводить сплошные санитарные рубки с последующим высаживанием лиственных пород.

Ключевые слова: категории состояния; индекс санитарного состояния; состав; полнота; сухостой.

V. Yu. Yukhnovskyi', I. A. Protsenko1, V. M. Khryk ${ }^{2}$

${ }^{I}$ National University of Life and Environmental Sciences of Ukraine, Kyiv, Ukraine ${ }^{2}$ Bila Tserkva National Agrarian University, Bila Tserkva, Ukraine

\section{SANITARY STATE OF PINE PLANTATIONS ON RECLAIMED LAND}

The purpose of the research is to determine the sanitary state of pine plantations on reclaimed lands, to identify the influence of biotic and abiotic factors on the changes in the sites and to provide recommendations for improving the biological resistance of pine forests in conditions of natural and man-made impact. The sanitary state of pine plantations created on the reclaimed lands of Yurkivskyi brown coal mine has been analyzed. Plants grow in difficult conditions on displaced, low-power soils with carbonaceous sands. The species composition of the lower tiers of forest phytocoenoses (undergrowth, understore, above ground layer), which is 
formed in medieval artificial pine plantations of fresh pine sites, indicates the restoration of flora diversity of reclaimed lands through forest amelioration. According to data of 61 circular test plots, which cover typical sites of pine plantations on the area of 141.1 hectares, indices of sanitary state of plantations have been calculated. The analysis of the sanitary index has shown that pine plantations are severely weakened. The weakened pine trees make up $44.7 \%$, and the sanitary index ranges from 3.01 to 3.41 . The state of pine plantations of the $\mathrm{V}$ age class is approaching the category of plantations that are drying up with the highest value of the state index of 3.41. Weakening of plantations may cause the spread of fires in the fire danger period, outbreaks of diseases and the spread of anthropomorphs. We have revealed that the most influential factors of the significant deterioration of the sanitary state of pine plantations on the reclaimed lands of the Yurkivskyi brown coal basin are dangerous to the root sponge and the drying of trees as a result of a decrease in the nutrition of plants that reached the disturbed maternal horizon at a depth of more than $40-50 \mathrm{~cm}$. In order to prevent the development of the root sponge, it is recommended to create mixed pine plantations with the introduction of up to $50 \%$ of deciduous, which at the same time will serve as a fire barrier for the spread of grass fires. For the improvement of pine plantations, increasing the reclamation efficiency and eliminating the cells of the root sponge, it is expedient to perform continuous sanitary felling with the subsequent planting of deciduous species.

Keywords: state categories; sanitary index; composition; density; deadwood. 